\title{
Мистецтвознавство
}

Удк 008: 130.2

\author{
Afonina Olena \\ Doctor of Art Studies, \\ Associate Professor of \\ National Academy of Culture and Arts Management \\ ORCID 0000-0003-1627-6362 \\ aolena7@gmail.com
}

\section{MUSIC OF MODERN BALLETS}

The purpose of the research is to identify various vectors in the use of music in modern ballets based on the analysis of works. Methodology. Typology method; comparative historical analysis; hermeneutic analysis in the interpretation of music of famous ballets; method of generalization for the conceptualization and expansion of new meanings of music, not created specifically for the ballet performance. The scientific novelty of the work lies in the identification of the dominant vectors in modern ballet music in performances of recent decades. Conclusions. Based on the analysis of some modern ballets, it can be concluded that in recent decades author's music for ballets has appeared. However, its percentage is very small. Often, production choreographers use famous classical music to interpret the libretto. Among the ballet performances of recent years, symphonic and chamber instrumental music is used in ballet performances.

Key words: classical ballet; modern ballet; author's ballet music; interpretation of the libretto.

Афоніна Олена Сталівна, доктор мистецтвознавства, доцент, доцент Національної академії керівних кадрів культури і мистецтв

Музика в сучасних балетах

Мета - виявити різні вектори у використанні музики в сучасних балетах. Методологія роботи. Метод типологізації; порівняльно-історичний аналіз; герменевтичний аналіз при трактуванні музики відомих балетів; метод узагальнення для концептуалізації і розширення нових змістів музики створеної не для балетів. Наукова новизна роботи полягає у виявленні домінуючих векторів у сучасній балетній музиці в виставах останніх десятиліть. Висновки. На основі аналізу деяких сучасних балетів можна зробити висновок, що за останні десятиліття з'являється авторська музика для балетів. Однак її відсоток дуже малий. Часто хореографи-постановники використовують відому класичну музику, інтерпретуючи лібрето. Серед балетних вистав останніх років в постановці балетів використовується симфонічна і камерно-інструментальна музика.

Ключові слова: класичний балет; сучасний балет; авторська балетна музика; інтерпретація лібрето.

Афонина Елена Стальевна, доктор искусствоведения, доцент, доцент Национальной академии руководящих кадров культуры и искусств

Музыка в современных балетах

Цель - на основе анализа произведений выявить различные векторы в использовании музыки в современных балетах. Методология работы. Метод типологизации; сравнительно-исторический анализ; герменевтический анализ при трактовке музыки известных балетов; метод обобщения для концептуализации и расширение новых смыслов музыки, не созданной специально для балетного спектакля. Научная новизна работы заключается в выявлении доминирующих векторов в современной балетной музыке в спектаклях последних десятилетий. Выводы. На основе анализа некоторых современных балетов можно сделать заключение, что за последние десятилетия появляется авторская музыка для балетов. Однако ее процент очень небольшой. Часто хореографы-постановщики используют известную классическую музыку, интерпретируя либретто. Среди балетных спектаклей последних лет в постановке балетов используется симфоническая и камерно-инструментальная музыка.

Ключевые слова: классический балет; современный балет; авторская балетная музыка; интерпретация либретто.

Relevance of the research topic. For centuries, ballet music has changed its purpose, but to a greater or lesser extent transferring the content of the work in musical-choreographic images. In the XVI century. in Italy, «ballet» was called a dance episode in the opera, which conveyed a certain mood in the general action of the opera. Gradually, with the receipt of the ballet of independent life, the composers G. F Handel, J. B. Lully, G. Purcell, J. F Ramo began to write music for the dance performance. For centuries, there have been reforms of the ballet theater, but the main achievements are connected with the dancer, choreographer and theorist of the dance Noverr. In his theoretical work «Notes on Dance and Ballet» the ballet reformer comprehended the previous experience of modern dance and developed a clause about the main changes in the ballet performance aimed at independence of the story line, enrichment with new elements of choreography and outlined the role of pantomime. This led to the introduction of a new ballet term «effective ballet». J. Nover invited composers to create ballet music, among which was Gluck. That is, the ballet reformer un-

(c) Afonina O., 2018 
derstood the importance of music for the embodiment of his ideas. The ballet music of P. Tchaikovsky with deep figurative content, principles of symphonic development and conflict dramatic art laid the foundations for the performances of the twentieth century. Therefore, the relevance of the problem of this article is to trace the main trends in the use of ballet music in contemporary Ukrainian choreographic performances.

The analyses of recent researches and publications. The Ukrainian ballet theater is dedicated to the monographs of Ukrainian musicologist Maria Zagaykevich: "Forest song. Ballet M. Skorulsky» (1963); «Ukrainian ballet music» (1969); «Ballet Drama» (1978). The main problems studied by M. Zagaykevich concern the drama of ballet, the analysis of the principles of the construction of the figurative system of the ballet performance, the interaction of its main components - music, libretto, choreography and scenography.

The theories and histories of contemporary choreography are studied in the works of such scientists and practitioners as A. Plakhotnyuk, M. Pogrebnyak, Yu. Stanishevsky, A. Chepalov, D. Sharikov, A. Shabalina and S. Shalapa.

The monographic study of Alexander Chepalov reveals the problems of the choreographic theater of Western Europe with the outstanding personalities of choreographers and their performances and characterizes the dance premieres of Maurice Bejart, Roland Petit and Pina Bausch.

Ballet music of recent decades exists in the hypostases specially written for performances and music that was not specially created for them. Among the Ukrainian composers, the author of many ballets is Yury Shevchenko. The music of his ballets «Buratino» and «Barmaley and Aibolit» is filled with bright humor. The musical themes of the heroes have subtle characteristics. Yury Shevchenko - a composer by nature is a melodist. But for the image of a wooden boy, Buratino, the composer chose a very non-flexible melody, emphasizing the material from which the character of the tale is made. According to the musical and rhythmic design of Yury Shevchenko, the image of Barmaley has a strong Cossack nature.

A new ballet by Yury Shevchenko "For Two Hares» with the choreographer-director Victor Litvinov according to the story of the play by M. Staritsky is a tragicomedy that was played in Kiev in the GoncharyKozhemyaki district. This district stretched from the St. Andrew's Church to Podol, that is, Kiev is also the character of the new ballet. The whole score of the ballet is permeated with intonations that appear in the canter, then in the polka, then in the waltz and even in the funeral march. An interesting find of the music of the ballet was the song «In the sky the canary is flying». It was written for the film «For Two Hares» by the Kiev composer Vadim Homolyak on the words of Yevgeny Kravchenko. Yury Shevchenko felt that the image of Golokhvastov and the plot of the play in general is simply forever connected with this song. Therefore, this song was the main musical theme of the new ballet.

Yury Shevchenko's melodic variety of music «For Two Hares» is understandable. Such intonations were imbued with Kiev atmosphere of the times of Staritsky's play. Morning on Kontraktova begins with a quadrille. Pronya learns to dance tango in a private salon. The waltz rhythm accompanies the sad Galya on Khreshchatyk. In addition, the music of the ballet has many motifs, close to folk songs. The play of M. Staritsky received a bright, grotesque musical embodiment in the ballet of $Y$. Shevchenko. Its basis is collage, although the author himself points to musical independence.

Modern Ukrainian composer and pianist Andrey Bondarenko wrote a number of ballets for children and young people such as «Maugliana», «Mukha-Tsokotukha», "Snow Queen», «Alice in Wonderland».

The ballet «Mukha-Tsokotukha» was created on the basis of the fairy tale of Korney Chukovsky. Music of A. Bondarenko combines all the best - the traditions and young musical professionalism of the XXI century. The composer aspires to bring the little performers of fairy-tale characters closer to modern musical art with means of musical expression. The ballet begins with a small overture, in which a tense atmosphere of expectation is transmitted. A short musical motif remotely resembling a buzz goes through all the instruments of the chamber ensemble (oboe, violin, cello). The development of the musical fabric is based on the repetition of the motif, which falls into the general sound of the chamber ensemble and on the background of jazz accompaniment of the piano leads to the theme of the Fly, with the characteristics of which the stage action begins.

The musical theme of the Fly is based on intonations close to folk. The active repeating motive conveys the elated mood of the heroine, who found the coin. The classical (Haydn, Mozart) ending with repeated repetition of the tonic confirms the positive situation. The next ballet number takes place in the bazaar, where only spiders are located first. Then they are joined by butterflies, grasshoppers and bees. A wonderful find of the author for spiders and all present at the bazaar is a jazz rhythm with short melodic rolls of wind and string instruments, creating an atmosphere of expectation of a miracle. When buying a samovar, the theme of Flies returns, which is the refrain of all musical ballet fabric. A. Bondarenko, as once S. Prokofiev in the symphonic fairy tale "Petya and the Wolf", arranges for all the meeting with the instruments of the orchestra. Each new character on the stage receives a vivid musical characteristic. In music, there are many allusions and reminiscences, which corresponds to the modern musical language, absorbing a variety of melodic and rhythmic turns from the history of music.

In the music of the ballet «Mukha-Tsokotukha» by A. Bondarenko there were many folk motifs and intonations of classical works with jazz rhythms. In the ballet music of Mauglian based on Kipling's fairy tale «Mowgli» from the appearance of Tiger, the composer uses the sound of modern popular music. In general, music is divided into several intonational blocks, emphasizing the images of good and evil. 
In addition to specially written music for ballet performances, choreographers often use music of different styles and genres, which was typical for the twentieth century as a whole. Although in the history of the ballet, there was something, when the entire performance was going on without music. In 1914, when asked by S. Diaghilev to stage a ballet on the themes of the «Gospel», the choreographer L. Myasin began to dance without music. All movements in six ballet scenes were performed without music. Choral music only sounded after the curtain fell on the stage [1, p. 149]. Later, the choreographer L. Myasin staged his famous ballet symphonies on the philosophical themes of being («The Sign» on the music of P. Tchaikovsky's Fifth Symphony, «Horeartium» on the music of Johannes Brahms's Fourth Symphony, Hector Berlioz's «Fantastic Symphony») [1, p. 149].

For example, French dancer and choreographer Roland Petit to the music of A. Vivaldi's concerts "The Seasons» made a choreographic composition (1984), in which the records of the ensemble I. Muzychi were used. The name "Seasons» is a cultural and historical tradition, coming from concerts of A. Vivaldi, Haydn's oratorio by the libretto of Baron Godfried van Sweeten on the basis of the poem by James Thomson (1801), the piano cycle by P. Tchaikovsky, less well-known opuses entitled «The Seasons» - the ballet of Marius Petipa on the music of A. Glazunov (1900) of the ballet of Mers Cunningham to the music of John Cage (1947).

This is also characteristic of the choreographic compositions of Ukrainian masters. The example is the ballet installation of Alexander Kozarenko "Don Juan from Kolomyia» (1994) based on the works of the Austrian writer L. von Sacher-Masoch "Venus in Furs». In the music of the ballet in Art Nouveau style, the composer introduced Hutsul motifs. The romantic cyclization of the three miniatures are previously written by the composer - «Oro» for the ensemble of drums (1994), «Inventions for four melodic instruments» (1989) and «Concerto Rutheno» for piano chamber music (1991). These works are one with a common intonation sphere, but for a different composition of instruments, which organically emphasizes each image of the ballet. For the work of Alexander Kozarenko, this ballet is not the only one. On his music «Sinfonia Extravaganza» and "Oresteia» ballets were also staged. "Sinfonia Estravaganza» (2013) (choreographers Vladimir Panteleimonov and Alexander Plahotniuc) continues the traditions of western European ballet of the early 20th century. It was these ballets that were based on music with the continuous development and refraction in the musical fabric of different musical styles of that time. In this ballet, reflections of precisely those traditions were found. Impossibility of the play, music for stringed instruments, the name of the ballet - "Sinfonia» allow the viewer and music listener to draw parallels with Balanchine's ballets, especially the ballet "Jewels».

Balanchine in three parts of the ballet used the music of various composers. The first part of «Emerald» is written on the music of Gabriel Faure («Pelleas and Mélisande», "Shylock»). In the second part of the «Ruby» choreographer used music by Igor Stravinsky (Capriccio for piano and orchestra). The third part of Balanchine's ballet «Diamonds» is based on symphonic music by Pyotr Tchaikovsky (Third Symphony).

The second part of A. Kozarenko's work, according to the composer himself, allusively leads the listener to jazz-blues intonations. In addition, A. Kozarenko's music is permeated with allusions to the ballets of I. Stravinsky and masterpieces-miniatures by M. Ravel, Prokofiev, Khachaturyan. Such a musical decision was prompted to the composer by the time, when the activation of the process of synthesis of arts (music, dance, theater, literature, cinema, video, carnival action) led to the emergence of a choreographic fantasy.

No less interesting is the musical decision in A. Kozarenko's play called Oresteia, where the codes of the ancient tragedy were used. The work of Kozarenko is written for artists, brass and percussion instruments. Modern reading of Aeschylus' texts about the death of Agamemnon from the hands of his wife and the revenge of his son Orest (translated by O. Sodomora, RM Rilke, O. Zabuzhko). Fragmentary music appears only in the sixth minute of the action. True, there is a text that is read by a reader. And then, on the tenth minute, a conductor appears on the stage and the brass winds are join by the percussion instruments. This occurs at the climax of the murder of Agamemnon by his wife.

Radu Poklitaru likes to use symphonic or chamber music in her ballets. For example, in the ballet "Hamlet" the choreographer refers to the music of two symphonies (No. 5 and No. 15) of Dmitry Shostakovich. Shostakovich has music specially created for the film «Hamlet». R. Poklitaru turned to Shostakovich's fifth symphony, because it caused him to associate with the ups and downs of such a Hamlet, which he had defined for himself in a ballet performance. His Hamlet is subject to frequent reincarnations, endowed with subtle lyricism with hints of humor and irony. These characteristics of Poklitaru coincide with the music of Shostakovich.

The images of Shostakovich's fifteenth symphony characterize the experiences of Hamlet, his close people and the meaning of life.

In the ballet triptych «Crossroads» R. Poklitaru uses the music of violin concertos (Second, Sixth and Seventh) by the famous Ukrainian composer Miroslav Skoryk. The ballet itself tells the story of human destinies like mythological plots.

The main idea of the ballet work is defined through the images of female goddesses from ancient Greek mythology, who spin the threads of life. In ancient Greek mythology, this is the goddess of fate Moira («Moira» in Greek means «share», "part», with the meaning of «fate» that every person receives at birth). First, in the representation of the ancient Greeks, Destiny was embodied in some inanimate object - fetishes, which was the carrier of vital forces, later - it was a magical force in a deity. 
One-act ballet «Long Christmas Dinner» by Radu Poklitaru, based on the play by the classic of American literature Thornton Wilder, unfolds to the music of Antonio Vivaldi «The Seasons». The action of the play-parable of the Bayard family to this music is perceived as something eternal and unchanging. The alternation of seasons as well as the alternation of generations of the Bayard family with love, birth, holidays, death. Ballet Poklitaru looks more like a performance with songs and dances to the music of eternal Vivaldi.

Ballet R. Poklitaru Pictures at an Exhibition (2002) was set to music of the famous cycle of M. Mussorgsky. Interesting idea Poklitaru about the plot of the ballet. Once Mussorgsky built his cycle on the transition from one picture of his friend Hartman to another. So, now Poklitaru heard in the music of Mussorgsky a fashion show in a modern art gallery. Next to the postmodern sculpture exhibition, a mystical ballet defile takes place under the direction of the treacherous Couturier. Each episode as if doubles into two pictures: the source itself and its modern reflection. Those present at the fashion show react differently to the action. Each character has its own plastic and musical arrangements.

In the well-known musical works of M. Mussorgsky, the choreographer places new plastic accents. The music of the long-standardized images of the cycle («The Walk», «The Dwarf», «The Ballet of the Unnoved Nestlings», "The Tuileries Garden». "Quarrel of children after the game», etc.) is harmoniously reflected in the movements of the dancers. Mussorgsky was inherent in operatic thinking, which penetrated into the "picture from the exhibition». Modern musicologists believe that the «pictures» are perceived as a musical «one-man show». The main musical principles in the ballet «Pictures from the Exhibition» are figurative contrasts that activate the passage of the show models through the picture gallery.

Classical libretto of ballets often finds new solutions in the performances of famous choreographers. Changes occur not only in the plots, but also in the music. For example, the favorite «Nutcracker» by $P$. Tchaikovsky in modern productions by M. Bejart or R. Poklitaru gets an unusual embodiment. In the ballet «The Nutcracker» (1999) M. Bejart in a new way reveals both music and plot sense. The main thing in ballet becomes the attitude of the choreographer to his childhood and the Mother. The main character of the ballet was the boy Bim, in contrast to the girl Clara in the ballet of P. Tchaikovsky. But Bim is a character from M. Béjart's previous ballet Paris Wedding (1978). For Christmas Bim has a mysterious object wrapped in white silk. When the boy wakes up, he sees that the gift has taken gigantic proportions, and this is a statue with a white marble female torso.

Bejart reads in a new way the image of Drosselmeyer, which appears in his ballet in the image of Faust, then Marius Petipa. These two personalities made an impression on him since childhood. The choreographer recalls how he first saw Faust at the age of ten and constantly played it along with his sister: she portrayed Faust, he - Mephistopheles [2]. From the screen of the scene, family photographs of Bejart look at the viewer, and he himself slowly tells exciting stories from his childhood, amusingly gesturing and fancifully weaving his fingers. In addition to Bejart himself, his grandmother appears on the screen, who, in particular, recalls that Maurice loved to dress in stage costumes and organize theater performances at home as a child.

In the Christmas ballet extravaganza there is also a large number of characters with real prototypes. Among them there are even two angels dressed in absurd costumes with golden lightning, whose heads are decorated with radiant crowns with feathers and makeup patterns on their bearded faces. It was in this extravagant form that some two brothers in America once performed, where M. Bejart personally met them [2].

In the second ballet act, a big gala performance is arranged by Beam with friends as a Christmas present for the mother. Four dances are very bright in ballet: Spanish, Chinese, Arabic and «Soviet» (instead of Russian). The performers are dressed in clothes that match the children's impression of M. Bejart. For example, if the Spanish dance used traditional clothes of matadors and even the head of a bull, then in Chinese - the artists are dressed in blue Maodz-Dyunivsk uniforms and ride bicycles. In the Arab dance in front of us there is a circus act with a magician, a suitcase and an actress. Soviet dance begins with the appearance on the scene of a red flag with a sickle and hammer, exclamations of the artist and reading the French text, symbolizing the Soviet era, which combines violence and grotesque. And at the snow ball, instead of snowflakes, schoolchildren dance in black cloaks and berets, which the choreographer wore during his childhood.

The most striking character of this performance is the god-fairy acordeonist. Indeed, the choreographer's godmother played the accordion, and together with his father and uncle they composed the musical trio. The men performed guitar and piano parts, respectively. A similar trio appears in one of the paintings of the ballet performance. For her role, M. Bejart invited a charming lady with a lush mop of bright red hair, which glorified France, phenomenally playing the accordion (Yvette Orner) [2]. The accordionist appears in the performance, traveling on a sleigh like a snow queen (reminiscence), each time in a new outfit, skillfully created especially for her by the famous Parisian couturier Jean-Paul Gautier. One of her magnificent dresses repeats the flag of France, since, according to national symbols, it consists of triplex blue, white and red.

Hybridization also touched ballet music. In addition to Tchaikovsky, whose music M. Bezhar retained without cuts, two interchangeable melodies appeared. The first melody is typically Parisian; it appears in the dance number of a street couple. It is performed by a trio with an accordion. Another tune (J. S. Bach) sounds in a room with M. Petipa. 
In general, the choreographer's fascinating dialogue with the classically romantic ballet (music, Hoffmann's characters), his childhood (mother's image, godmother, personal impressions of Petipa, Faust) uses allusions to famous fairy tale heroes conquered by the great master's fantasy.

Ernest Theodore Amadeus Hoffmann's fairy tale «The Nutcracker and the Mouse King» is embodied in a different way by the choreographer R. Poclitaru (2007). The connotations of the work of Hoffmann inherited the symbols of the Christmas holiday, and Tchaikovsky's ballet music does not change. It just doesn't get the usual visual solution, when they perform «Waltz of Flowers» in luxurious costumes.

In the ballet «Cinderella» by J. C. Mayo the transformations touched all the components of the production. The character of the evil Stepmother has disappeared from the libretto. She turned into a seductive woman with two pretty daughters. Cinderella is as if left an orphan with his father, who was completely dissolved in his new love. But the Fairy appears and the fairy tale begins. In her image of Fairy, Cinderella recognizes her deceased mother, like Tiltil and Mitil from Bluebird. Ballet Fairy is engaged in Cinderella. The choreographer has lost his father. Now fantastic characters (Cinderella, Fairy-Mother) combine the world of the living and the souls of the dead. It seems there is no longer Cinderella, and the Fairy Mother is the main character, who tells Cinderella about her happy future. Mayo refuses even crystal shoes, changing them to gold sparkles, on which the Prince will find his bride. A golden rain covered the lovers' fairy in the final. And at the ball, instead of the romantic Waltz of Cinderella and the Prince, a merry campaign with bare torsos danced a cancan.

In general, Prokofiev's music remained in the ballet. Mayo removed the spatial musical moments, concentrated on the text and supplemented the score with fragments from the music for the film «Lieutenant Kizhe».

Conclusions. Based on the analysis of some modern ballets, it can be concluded that in recent decades author's music for ballets has appeared. However, its percentage is very small. Often, production choreographers use famous classical music to interpret the libretto. Among the ballet performances of recent years, symphonic and chamber instrumental music is used in ballet performances.

Ballet music can combine several composers and several works. It depends only on the choreographer, who conceives the performance. It can include both works as a whole, tech and fragments. The topic of the article is inexhaustible, because ballet music today is of great interest among the public, performers and choreographers.

\section{תimepamypa}

1. Погребняк М. Неокласицизм у хореографічних театрах Л. М'ясіна, Б. Ніжинської, Ф. Лопухова як сходинка до неокласичного стилю у театрі Дж. Баланчина // Вісник Львівського університету. Серія мист-во. 2015. Вип. 16. Ч. 2 С. $147-155$. ния: 17.06.17).

2. Щелкунчик: фильм балет. URL: http://xn--e1aaowadjh.org/forum/ viewtopic.php?t=186592 (дата обраще-

\section{References}

1. Pogrebnyak M. (2015). Neoclasicism at the choreographic theaters of L. M'yasina, B. Nizhinskyi, F. Lopukhov and Yak Shodinka to neoclassical style in the theater of J. Balanchine // News of Lviv University. Seria myst. 2015. Vip. 16. Part 2. Pp.147- 155 [in Ukrainian].

2. The Nutcracker: film ballet. URL: http://xn--e1aaowadjh.org/forum/ viewtopic.php? T = 186592 (access date: 17.06.17) [in Russian].

Стаття надійшла до редакції 18.09.2018 p. 